\title{
"MISTY POETRY" AS A REFLECTION OF THE NATURE OF CHINESE LITERATURE OF THE “NEW PERIOD” (SECOND HALF OF THE 20TH CENTURY)
}

\author{
Ivan Semenist \\ Borys Grinchenko Kyiv University \\ vul. Marshala Tymoshenka, 13Б, Kyiv, 04212, Ukraine \\ (D) https://orcid.org/0000-0002-0847-8856 \\ i.semenist@kubg.edu.ua
}

\begin{abstract}
The subject of the study is the formation of "Misty Poetry" trend in Chinese literature of the late $20^{\text {th }}$ century. The study aims at the disclosure of the dynamics of "Misty Poetry" within modernist paradigm against the backdrop of Chinese literature of the "New Period". The method is grounded in identification of key modernist poetics categories, perceived and transformed in the versification practice of Misty Poetry. Sociocultural contextualization method is employed to locate Misty Poetry in the post Cultural Revolution aesthetic and ideological context of China. The study results cover the lyrical attempt at a modernistic search for identity in Chinese literature of the "New Period". The pursuit of self and vaster category of identity is considered and comprehensively analyzed through the array of representative poetic texts (Zhang Ming, Meng Lang, Bei Dao, Duo Duo). "Misty Poetry" marked the beginning of the "New Period" in the history of modern Chinese literature. The trend demonstrated qualitative changes in the ideological foundations and artistic practice of the new poetry of China in the 20th century. "Misty Poetry" became a kind of aesthetic protest against the ideological and artistic clichés of the preceding cultural-historical era. The concept of "self" within the paradigm of Misty Poetry is corroborated to be perceived as an independent consciousness, not dictated by any ideology or doctrine, disclosed through the means of a poet's internal thoughts depictions, both conscious and subconscious. The paper results demonstrate the transformative potential of the Misty Poetry trend poetics on prosodic level, level of stylistic imagery and genre specificity. The paper interpretative results explore the significance of the "Misty Poetry" in the way that it revived and gave a new impetus to the further development to the humanistic orientation of Chinese poetry. The novelty is connected with the aesthetic means of territorializing the marginal space that provides the poet and the poetic protagonist with a critical distance from the dominant discourse of the political-cultural establishment of post Cultural Revolution China are disclosed. The paper concludes the Misty Poetry trend drew attention to the subjective beginning in art and opened the discourse for an active search for a new artistic reality in which the legacy of classical poetry of China, the best humanistic traditions of the new poetry of the early 20 th century and the modernist features of Western poetry were combined.
\end{abstract} China.

Keywords: Misty Poetry; Chinese literature; Menglong shi; Cultural Revolution; Modernism;

Introduction. In the late $1970^{\text {s, }}$, the emergence of many young poets became a major phenomenon in Chinese poetry circles. Due to the special historical and socio-political circumstances of the "Cultural Revolution" in China, there was a "gap" where there would normally have been writers and artists of a certain age group. At the time, among those listed in this grouping of young poets were Lei Shuyan, Ye Wenfu, Luo Gengye, Zhang Xuemeng, Yang $\mathrm{Mu}, \mathrm{Qu}$ Youyuan, Ye Yanbin, Gao Falin, Chen Suoju, and Fu Tianlin, as well as those termed "Misty poets" such as Bei Dao and Shu Ting (Hong, 2007, p. 335).

Previous research overview. The peak of the research on "Misty Poetry" in China was in the $80^{\text {s }}$ of the past century, as evidenced by a large number of literary and critical works. These are the investigations of literary critics, writers, and poets, such as Xie Mian, Gu Gong, Ai Qing, Zhan Ming, and others. Chinese people are still interested in "misty poems": there are new inquiries into the study of various aspects of this movement as a whole, as well as the creative output of its representatives. Books and academic papers by Hong Zicheng, Liu Yung, and other researchers should be taken into account as well.

Works of the authors of "misty poems" were studied by such European scholars as Bonnie S. MacDougall, J. Michel, P. Harris, and others. American scholars S. Liu, C. Luo, and D. Lee consider "Misty Poetry" in the general context of Chinese culture modernization of the 20th century, also in the context of cross-section between Western and Chinese poetry. Thework of a scientist from Leiden University (the Netherlands) M. Crevel, deserves a special mention. M. Crevel compiled a bibliographic description of books and articles on Chinese avant-garde poetry published in the People's Republic of China and Taiwan. Brief annotations for the publications listed in this work have been very helpful for us in finding and 
selecting referential bulk of literature for this study. In the recent years Ukrainian literary scholars pay more attention to the works of Chinese Misty poets. The works of the following researchers deserve due attention: Y. Bezverkhnya, D. Vyshnyak, K. Murashevych (Bezverkhnya, 2014; Vyshnyak, 2015; Murashevych, 2013).

Methods. The theoretical and methodological basis of the study is comprised of the works of Chinese scholars and critical proponents: Xie Mian, Sun Shaozhen and Xu Jingya, Jing Wang, Tang Xiaodu, Gu Gong, Ai Qing, Zhang Ming, and others, also proceedings of a Western scientist Xudong Zhang. The study methodic design is grounded in identification of key modernist poetics categories, perceived and transformed in the versification practice of Chinese "Misty Poetry". The study objective, therefore, is to derive the dynamics of "misty poetry" within modernist paradigm against the backdrop of Chinese literature of the "New period". The overall anthropocentric approach is implemented to derive the peculiarity of Misty Poetry movement aesthetics. Sociocultural contextualization method, in particular, is employed to locate Misty Poetry in the post Cultural Revolution aesthetic and ideological context of China. A subset of conceptual interpretation methods is used to corroborate the use of imagery, peculiar to the "Misty Poetry" aesthetics.

Findings. Zhang Ming is the poet who first used the term "menglong" ("mist") in his critical article "The «Mist» That Makes One Brood" - "Ling ren qimende" "menglong" (He, 2001). First poems were kept by their authors, circulated among friends, or published in such an unofficial journal as "Today". Popular love poetry, published by the official press appealed to a large audience and made a considerable profit, but most of the Newborn Generation poetry was published in mimeographs by individual poets or groups of poets and was of extremely limited circulation. In 1979 many local literary journals published works of young poets. There were numerous poems published by the "Anhui Literature" journal. The most prestigious journal devoted to poetic artists - "Poetry" - even organized a short seminar for young poets in 1980 .

For the poets of the Newborn Generation, as for the Menglong poets, poetry is both a symbolic and a real means of territorializing the marginal space that provides the poet with a critical distance from the dominant discourse of the political and cultural establishment. A fine distinction between the two groups can be devised in the following consideration: the younger poets probably feel an added sense of marginality in the increasingly commercialized society of post-Mao China.

To attest to the prior statement, let us consider one of Meng Lang's poem opening lines:

Learn to breathe untrue air

Before uttering

True words.
At moments like this I write poetry

And lie.

Those who live in the buildings

Are all my best friends.

It's a pity I don't know any of them.

The poem ends with the speaker committing a symbolic suicide with a revolver:

\section{I shall die truthfully \\ In the untrue air. (Michelle, 1992, p. 37)}

The first stanzas indicate a fundamental lack of trust and communication between people. The poet turns to poetry, where he can be true to himself, but he lies (or has to lie) when dealing with the outside world. The ambiguous juxtaposition of writing poetry and lying is a subtle subversion of the establishment's disapproval of the new poetry - from Menglongshi to the poetry of the Newborn Generation - as lies about the society when, in fact, the poetry is telling the truth. The choice for the poet, suggested by the ending of the poem, is between truth (of poetry) and death (of the poet's soul).

Caught between political dogmas and the commercialization of poetry, Meng Lang, in the poem "Winter", implied the rejection of both:

Poetry points to poetry itself.
I throw a jacket on,
Go through the empty lot,
And disappear from this city. A bronze statue -
I cannot put my foot in it.
Poetry points to the heart.
The four walls are white as snow;
The vacant room is habitable-
Quite the contrary. Let us walk through
This empty lot, through city,
Through poetry itself.
Then we will settle down,
Make a fire, take off our jackets
And our underwear,
And expose our bodies. We will face poetry
Or turn against it. (Meng, 1995, pp. 37-38)

In this framework, "Misty Poetry" ("Menglong shi") or the Menglong movement developed into the first distinctly modernist attempt in the Chinese literature to study and reconstruct the sociopolitical and the aesthetic experience outside the mainstream. The roots of the "Misty Poetry" did not necessarily have something in common with the later variations of modernism, but it would be impossible to explain the meaning of, for example, modernist or the avantgarde prose without paying at least some attention to the first attempts to create a new discursive space.

Since the artists of the "Misty Poetry" movement appeared in China at the end of the period, commonly referred to as "Cultural Revolution", for the poetic revolution they sought to create an aesthetic space free from politics. They also strived to establish 
self-affirmation in this space. Their earliest works, diverse in orientation and heterogeneous in quality, appeared in the middle and even in the early $1970^{\text {s. }}$. "In the atmosphere of the total dictatorship of the proletariat, individuals tried to preserve their life experiences, feelings, and memories for the future, to express anxiety and hope, and to resist violence against the language" (Zhang, 1997, p. 127).

Influenced by specific social, political and intellectual circumstances that developed in the 1980s, the poetic language of the "Misty Poetry" was adopted as an ideal, aesthetic model, the future for the Chinese literature. The contradiction between politics and aesthetics was "resolved" by searching for the severity of form (initially it was romanticism rather than modernism), which was compatible with the personal or collective life experiences, lived through by the poets during the sociopolitical storms of the $1960^{\mathrm{s}}$ and the $1970^{\mathrm{s}}$. Both the socio-empirical content and the aesthetic aspect of the "Misty Poetry", adjacent to it, were clear and accurate for the part of society to which they turned. The first readers felt that the tip of the "Misty Poetry" was pointed against collective "expression" or "expressiveness", in defense of personal, artistic experimentation. "The Answer", by Bei Dao, is a poetic manifesto and one of his most frequently quoted poems from those written in the early period of the Menglong movement reflects the sociopolitical situation and the significance of Chinese modernism in the post-Maoist era.

It begins with the following lines:

\section{Debasement is the password of the base, Nobility the epitaph of the noble. See how the gilded sky is covered With the drifting twisted shadows of the dead.}

The conceptual core of the poem is the fourth quatrain:

\section{Let me tell you, world, \\ I-do-not-believe! \\ If a thousand challengers lie beneath your feet,} Count me as number thousand and one. (Bei, 1988)

It is worth drawing attention to modernism motives proper in the "Misty Poetry". Modernism in China formed on the ruins of the "Cultural Revolution". The fact that it presented itself and was rather perceived as an "aesthetic" trend is connected with the socio-ideological need that existed at that time for restoring "value", "meaning", "worldview", and with its help, one could comprehend the past and the future. Humanism as the construction of Chinese socialist subjectivity is one of the frameworks uniting values and ideology, that can be seen as a revival of the spirit of the Chinese enlightenment of the May 4th era. This revival, understood as a return to the values of the May 4th Movement, points to the aesthetic radicalism declared in "Misty Poetry", which thickens the panorama of social life into intense tragic conflict expressed through personal experience and subjective consciousness.

In the "Misty Poetry" imagery two internal motives of modernism in the spirit of May $4^{\text {th }}$ can be recognized: the conviction of the need for national revival and the intellectual fear of physical poverty and moral paralysis of Chinese society and shame for it. The modernist drama, the culmination of which in the era of May $4^{\text {th }}$ became a realistic form of expression, is depicted in the "Misty Poetry" as overcoming the external with the help of the internal nature through art. Chinese modernism at an earlier stage remained in the shadows, perceived as a useful, but, in general, an alien sign system expressed only in selective proximity by some Chinese poets and writers. In case of the "Misty Poetry", it becomes a kind of symbolic space in which the collective "Self" is formed through linguistic processes (Zhang, 1997, p. 129).

According to the words of Xudong Zhang, this distinction between the modernist poets of the $1930^{\mathrm{s}}$ and the Menglong movement indicates a significant destruction of tradition over the past decades of Chinese history (across the spectrum, from the cultural world of Chinese literature to the social, moral and political aspects of the personality of the Chinese intellectuals). The subsequent development of Chinese culture showed that tradition was not destroyed even under the influence of globalization processes. Probably representatives of the "Misty Poetry" were still too sociologized, which can be explained by their temporal proximity to the "Cultural Revolution" timespan.

One of the most active supporters of the Menglong movement - Jingya Xu - summarized the artistic features of the new poetic style in the article "The Rising Poems", published in 1983 in the journal "Modern Artistic Trends". When talking about the "new tendencies" of the Chinese New Poetry as a natural end-result of its internal contractions, Jingya $\mathrm{Xu}$ pointed out that such vast social turbulence as the Cultural Revolution and such extreme distortion of many souls in the turbulence inevitably formed a strong force to break the restraints in the soul, thereby giving rise to a literary revolution. Poetry, as the most intimate friend of human nature and the most direct link between an individual soul and the external world, inevitably underwent a radical transformation. These so-called "boasting poems", "ossified poems", and "slogan-like poems that cover-up and deceive" have pushed the art of the New Poetry to the transform-or-die limit. Now, a thourough change has taken place concerning the artistic appreciation of a whole generation. This is a selfnegation of the New Poetry - an inevitable negation in literature accompanying the negation in society.

Furthermore, Jingya Xu believed, in the long run, the new tendencies, as can be seen in the "Misty Poetry", will become the mainstream of Chinese poetry. It will take a long time through, during which orthodox poetry and modernist poetry will coexist. He also believed at the moment the new poets could 
form schools. In the past 30 years, people almost lost hope of having different schools and styles and they did not understand that there must be some prerequisites before they are formed. According to Jingya $\mathrm{Xu}$, the first prerequisite is a unique social outlook that can even be disharmonious with the concerted keynote of the society. Another prerequisite is a unique artistic stand which even dares to deny the "eternal answer", and opens up new poetic realms. And the last prerequisite is social protection of special aesthetic interest and appreciative ideals in literature (He, 2001, p. 738).

Many contemporaries perceived his works as a manifesto of modernism in China. According to Jingya $\mathrm{Xu}$, the emergence of the "Misty Poetry" brought to life a new sense of "Self" in Chinese literature "Self", completely different from what the reader in the "Mao era" literature used to see. This "Self" has an independent consciousness, not dictated by any doctrine. This new consciousness gives privilege to the poet's internal thoughts, both conscious and subconscious. The "Self" rising from this consciousness thus expresses and glorifies itself. Jingya $\mathrm{Xu}$ gave a long list of artistic and utilitary techniques of a new form of expression, which he calls Chinese modernism: deep symbolism, many different points of view, distortion, installation, expression of the initial and/or specific moments of feeling and consciousness, correlation, etc. (Xu, 1983, pp. 18-23).

During the campaign "For the Eradication of Spiritual Pollution" of 1983, streams of criticism poured over Jingya $\mathrm{Xu}$ in which, in deference to the output of Marx and Engels, it was argued that the poet should never be separated from the collective course and that the poetic "Self" should be connected with the "Self" of the people. Jingya Xu was accused of blindly worshiping Western bourgeois values — individualism, humanism, existentialism.

Confidence in correlation, as an artistic method, a persistent concentration on metaphorical images in the early works of the Bei Dao and Mang Ke, Shu Ting, Jiang He, Yang Lian and also Gu Cheng, the persistent desire for autobiography or self-references from Duo Duo and almost every representative of the "Misty Poetry", are characteristics not so much of an individual creative manner (a myth, which, according to Xudong Zhang, was still maintained), but of social enthusiasm that increases the value of personal selfknowledge, collective action, and imperatives on which the poetic expansion based the concept of "Self". The prosodic mechanism based on the restoration of the self-relieving subject as the center of the universe and the administer of feelings becomes an aesthetic "response" to the demands of the masses. The relationship between the author and the reader reflects the unique sociopolitical situation in China in the early post-Maoist period.

The name of the poem "The Answer" written by Bei Dao belies social imagination and ideological belief that there is something that needs to be answered, and what it is possible to answer in principle.
The ability to convey social experience is hampered by the addition of a system of symbols called modernism. At the same time, the subjective, poetic desire to enter into dialogue with the public is supported by the creation of the image of an artist whose social function is based on the exaggerated importance of personal and professional status, dignity and prestige. This political interaction between the individual and the collective defines two stylistic tendencies of the Menglong movement - the lyrical tendency and the passion for the epic. Another poem "Declaration" (Bei Dao) is considered "a vivid example of political lyrics" (Wu, 1988, p. 1343). And although the poem is dedicated to a specific person - Loke Yew - it is addressed to every person and everyone who survived the "Cultural Revolution":

Perhaps the final hour is come

I have left no testament

Only a pen, for my mother

I am no hero

In an age without heroes

I just want to be a man

The still horizon

Divides the ranks of the living and the dead

I can only choose the sky

I will not kneel on the ground

Allowing the executioners to look tall

The better to obstruct the wind of freedom

From star-like bullet holes shall flow

A blood-red dawn. (Bei, 1988)

Even a superficial acquaintance with the texts of the "Misty Poetry" movement is enough to conclude that the subject of poetic imagination is a depressing past rather than an alluring future. However, collective memory is not used as shared memories but as a "psychological reservoir" and "repository of symbols". From this general "data bank" material is drawn for the formation of an egoistic, closed-loop system of poetry as such, which, however, does not prevent the poet from choosing a particular form of expression in each specific work (ranging from epic to lyrical). The penchant for romantic lyrics is fully manifested in poems of Duo Duo.

Below are indicative excerpts for the "Promise", written by Duo Duo:

I love, I love my shadow

Being a parrot, I love eating

What it loves eating, I love giving you what I don't have

I love asking: Do you still love me?

...

I love even more that we are still a pair of torpedoes

Waiting for someone to launch us again

I love rejoining you in the depths of the sea, you

Are mine, only mine, I

Still love speaking like this, like this, singing

of my promise. (Duo, 2008) 
As for the epic tendency in the "Misty Poetry", its style is determined by the position of opposing "gaps" in life experience, which, in turn, are projected onto historical or transhistorical "gaps". The intention proclaimed by Yang Lian to cross two thousand years of literary stagnation to revive the traditions of $\mathrm{Qu}$ Yuan (the cycle of poems "Qu Yuan"), and the desire of Jiang He to designate the space of the modern epic (cycle "Mythology") are only two manifestations of a transhistorical vision of a concrete historical experience, which determines the sharpness and scale of the drama of poetic imagination.

Representatives of the "Misty Poetry" tried to build an aesthetic space in which their collective past is expressed as a metaphysical picture of history. Allegories that permeate their work are only the simplest manifestations of stylized timelessness, which in the middle $1980^{\text {s }}$ was revealed in many writings on the "Search for roots" trend. It was creativity intertwined with social utopia.

The public was not tired of the "Self" that flourished in the works of the "Misty Poetry", while the construction of aesthetic subjectivity became a profession of the cultural elite, which successfully formed a separate layer. For a more mature postrevolutionary society, for an era of an individual lifestyle preferred by the people, this subjectivity became a burden.

"In the sense of the internal conflict through which representatives of «Misty Poetry» manifested themselves, they remain modernists in the classical sense - same to Charles Baudelaire manner, they add weight to the experience lived through" (Zhang, 1997, pp. 135-136). They "indicated the price to be paid for the feeling of modernity" like Charles Baudelaire. It is necessary to survive the collapse of the historical era in the process of a shocking clash with "World Poetry". They desperately tried to become a part of it, concentrated on building their aesthetic dome under which their wandering souls could live, free from constant contact with political turmoil, material shortages, cultural poverty and shame for being left out of the modern feast. They were convinced that poetry should be higher than politics and that the poet must also penetrate the darker spiritual depths to obtain the poetry trophy.

Conclusion. The reactivation of modern Chinese literature by the Menglong movement and its contribution to the Mandarin Chinese language as a source of poetics is unquestionable. The investigation demonstrates the transformative potential of the Misty Poetry trend poetics on prosodic level, the level of stylistic imagery and genre specificity. The study findings disclose the significance of the "Misty Poetry" in the way that it revived and gave a new impetus to the further development to the humanistic orientation of Chinese poetry. Specifically, the aesthetic means of territorializing the marginal space that provides the poet and the poetic protagonist with a critical distance from the dominant discourse of the political-cultural establishment of post Cultural
Revolution China are revealed. Representatives of the "Misty Poetry" movement sought the transcendence of poetry so passionately that they turned poetry (and modernism itself as a paradigm) into a cult object. This cult object manifests itself as an emerging subject and an ideological vision. In this vision, the panorama that modernism contemplates with a supportive distrust at some distance is not a street fair in Beijing, but a global market. As stratification in the social sphere became less and less murky, the "Rebels" realized that the masses had betrayed them. They did not find a place for their subjectivity in the new world, which they could only imagine and which they could refer to only in metaphysical terms. It was at that moment that the alienation became complete. And at that very moment, their ideology finally gained expression through language. The study paves the prospective avenues of further investigations into arrangement, coordination and verbalization of aesthetic categories and implementation of corresponding aesthetic practices of the "Misty Poetry" movement. The study presents the potential of inquiry into the way Misty Poetry aesthetic method informs the vaster framework of early 21st century Chinese literature.

\section{References (translated and transliterated)}

Bei, Dao (1988). Declaration. Poetry Foundation (Bonnie S. McDougall, Trans.). https://www.poetryfoundation.org/ poems/142178/declaration.

Bei, Dao (1988). The Answer. Poetry Foundation (Bonnie S. McDougall, Trans.). URL: https://www.bbc.co.uk/ worldservice/arts/features/poems/transcripts.shtml

Bezverkhnya, Y. (2014). “Tumanna poeziya” v kytays'kyy literaturi kriz' pryzmu tradytsiy ta novatorstva ["Misty poetry" in Chinese literature through the prism of tradition and innovation]. Literaturoznavchi studiyi [Literary Studies], 42(1), 74-80. Kyiv.

Duo Duo (2008). Promise. World Literature Today (Yibing Huang, Trans.). https://www.worldliteraturetoday.org/2011/march/ three-poems-duo-duo-bilingual-texts\#.UZWJybXvtfs.

He, Henry Yuhuai (2001). Dictionary of the political thought of the People's Republic of China. New York.

Hong, Zicheng (2007). A History of contemporary Chinese literature (Michael M. Day, Trans.). Leiden, Boston, Brill. https://doi.org/ 10.1163/ej.9789004157545.i-636.

Meng, Lang (1995). "Winter" ("Dongtian”). In Bei Ling, Meng Lang (Eds.). Seventy-Five Contemporary Chinese Poems (pp. 37-38). Beijing.

Michelle, Yeh (1992). Anthology of modern Chinese poetry (Michelle Yeh, Ed.). New Haven, London, Yale University press.

Murashevych, K. (2013). "Tumanna poeziya" yak fenomen kytays'koyi literatury druhoyi polovyny XX st. ["Misty Poetry" as a phenomenon of Chinese literature of the second half of the $20^{\text {th }}$ century]. In China, Korea, Japan: methodology and practice of culture interpretation (pp. 150-154). Kyiv, Seoul.

Vyshnyak, D. (2015). Kontseptualizatsiya smerti v poeziyi Hu Chena [The conceptualization of death in the Chen Gu's poetry]. Literaturoznavchi studiyi [Literary Studies], 44(1), 80-89. Kyiv.

$\mathrm{Wu}$, Benshin (1988). Great Dictionary of New Chinese Poetry with commentary (Zhongguo xinshi jianshang da ci dian) (Wu Benshin, Ed.). Wuhan.

$\mathrm{Xu}$, Jingya (1983). The rising poetry group - reviewing the modern trend of traditional poetry (Jueqi de shi qunping woguo shige de xiandai qingxiang). Contemporary literary trends (Dangdai Wenyi Sichao), 1, 55. Beijing Shi.

Zhang, Xudong (1997). Chinese modernism in the era of reforms. Cultural fever, avant-garde fiction and the new Chinese cinema. Durham and London: Duke University Press. 


\title{
«ТУМАННА ПОЕЗІЯ ॥ ЯК ВІДДЗЕРКАЛЕННЯ ПРИРОДИ КИТАЙСЬКОЇ ЛІТЕРАТУРИ «НОВОГО ПЕРІОДУ» (ДРУГА ПОЛОВИНА ХХ СТОЛІТТЯ)
}

\author{
Іван Семеніст \\ Київський університет імені Бориса Грінченка, Україна
}

\begin{abstract}
Предметом дослідження $є$ формування течії «Туманної поезії» в китайській літературі кінця XX століття. Мета статті - розкрити динаміку «Туманної поезії» в межах модерністської парадигми на тлі китайської літератури «Нового періоду». Методика дослідження грунтується на ідентифікації ключових категорій модерністської поетики, що сприймаються і трансформуються в практиці версифікації течії. Метод соціокультурної контекстуалізації використовується для визначення місця «Туманної поезії» в естетичному та ідеологічному контексті Китаю періоду після Культурної революції. Результати дослідження виявляють ліричні спроби модерністського пошуку ідентичності в китайській літературі «Нового періоду». Пошуки власного «Я» та прагнення ширшого визначення категорії ідентичності розглядаються та всебічно аналізуються на матеріалі загалу репрезентативних поетичних текстів (Чжан Мін, Мен Лан, Бей Дао, Дуо Дуо). «Туманна поезія» поклала початок «новому періоду» в історії сучасної китайської літератури. Ця літературна течія продемонструвала якісні зміни в ідеологічних засадах і художній практиці нової поезії Китаю у XX столітті. «Туманна поезія» стала своєрідним естетичним протестом проти ідейно-художніх кліше попередньої культурно-історичної епохи. Поняття «Я» в межах парадигми Туманної поезії достовірно ідентифікується як незалежна свідомість, не продиктована жодною ідеологією чи доктриною, розкрита за допомогою зображень внутрішніх думок поета, як свідомих, так і підсвідомих. Результати дослідження демонструють трансформаційний потенціал поетики течії «Туманної поезії» на просодичному рівні, на рівні стилістичної образності та в жанровій специфіці. Інтерпретативні результати дослідження виявляють значення «Туманної поезії» в тому, що ця течія відродилась і дала новий поштовх для подальшого розвитку гуманістичній орієнтації китайської поезії. Новизна дослідження полягає в розкритті художніх засобів освоєння маргінального простору, що забезпечують поету та ліричному герою критичну дистанцію від панівного дискурсу політико-культурного істеблішменту в добу після Культурної революції в Китаї. Дослідження підсумовує, що течія «Туманна поезія» поставила у фокус суб’єктивне начало в мистецтві та відкрила дискурс для активних пошуків нової художньої дійсності, у якій поєднані спадщина класичної поезії Китаю, найкращі гуманістичні традиції нової поезії початку XX століття та модерністські риси західної поезії.

Ключові слова: Туманна поезія; китайська література; менлунши; культурна революція; модернізм; Китай; Культурна революція.
\end{abstract}

